\title{
TOTAL SUSPENDED PARTICULATES FROM CRUDE OIL SPILL
}

\author{
OYETUNJI BABATUNDE OKEDERE ${ }^{1 *}$, ADEWOLE JOHNSON ADESANMI ${ }^{2}$, \\ JACOB ADEMOLA SONIBARE ${ }^{3}$, OLUSOLA ADEDAYO ADESINA ${ }^{4}$, GBADEBO \\ OMONIYI ADENIYI
}

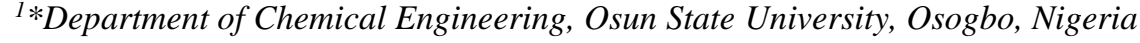 \\ ${ }^{2}$ Laboratory Research \& Bioresources Development Centre, Akoko, Nigeria \\ ${ }^{3}$ Department of Chemical Engineering, Obafemi Awolowo University, Ile-Ife, Nigeria \\ ${ }^{4}$ Department of Chemical Engineering, Afe-Babalola University, Ado-Ekiti, Nigeria \\ ${ }^{5}$ National Space Research and Development Agency, Federal Ministry of Science \\ and Technology, Nigeria
}

\begin{abstract}
Total suspended particulates emitted during crude oil spill were investigated using laboratory simulation experiments. This was with a view to establishing the toxicity potentials of emitted particulates. Climatic and spill media conditions similar to those obtainable in real life were created in an environmental chamber and the total particulates emitted during spills involving three crude oil samples of Nigerian origin were measured with Quick Take sampler. The toxicity potentials of the emitted particulates were subsequently determined by dividing the 24 - hour averaging period concentrations of the particulates by the statutory limit. The statutory limits used were those of Nigeria's Federal Ministry of Environment (FMENV), World Bank and the World Health Organization (WHO). For temperatures between $15^{\circ} \mathrm{C}$ and $35^{\circ} \mathrm{C}$ and spill media (over fresh water, sea water and soil), the extrapolated 24 - hour averaging period concentrations ranged between

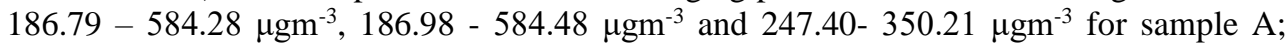
$183.44-571.99 \mu \mathrm{gm}^{-3}, 183.63-572.19 \mu \mathrm{gm}^{-3}$ and $244.05-337.92 \mu \mathrm{gm}^{-3}$ for sample B and $178.41-566.96 \mu \mathrm{gm}^{-3}, 178.61-567.16 \mu \mathrm{gm}^{-3}$ and $332.89-280.60 \mu \mathrm{gm}^{-3}$ for sample C. The observed TSP concentrations breached the WHO (lower limit) and World Bank limits at all temperatures and over all spill media and consequently the toxicity potentials exceeded 1.0 which were indications of hazards to human health. The study concluded that particulate emissions during crude oil could be high enough to pose threats and suggested adequate protection for cleaning up workers.
\end{abstract}

Keywords: oil spill, total suspended particulates, toxicity potential

\section{INTRODUCTION}

The increasing interest in ambient particulates is as a result of their deleterious effects on human and environmental health [1 - 4]. The toxicity of ambient particulates can be by intrinsic properties or by combining with other harmful pollutants [5 - 7]. Particulates by nature have intrinsic properties of being dangerous due to their size, roughness

\footnotetext{
${ }^{*}$ Corresponding author, email: oyetunji.okedere@uniosun.edu.ng

(C) 2021 Alma Mater Publishing House
} 
and surface area. When in the respiratory track, they can cause difficulty in breathing and damage to respiratory organs $[8,9]$. Depending on size, they get deposited at different depth in the human body ranging from nasal cavity to bronchi and the alveoli $[10,11]$. They may be transported to the cardiovascular system and the rest of the body $[8,9]$. Inhalation of particulates has been reported to cause oxidative stress, aggravate heart disease, mortality etc. [12 - 14]. They can also serve as conveyors for other hazardous pollutants [15]. According to the studies by [15] and [16], particulates can provide surface for adsorption of pollutants like polycyclic aromatic hydrocarbons (PAHs), persistent organic pollutants (POPs) and a host of other harmful pollutants. The sources of ambient particulates are ubiquitous and include natural and anthropogenic activities. Natural sources of particulates include volcanic eruptions, sea sprays, sand storm, natural crude seepage etc. Most anthropogenic sources of particulates are combustion related.

In Nigeria, there have been several studies on ambient air particulates (PM) from anthropogenic activities. The effects of vehicular emissions on ambient air PM have been investigated by [5]. The impacts of gas fired thermal plants for electricity generation on air pollutants including PM have been studied by [17]. Others include particulates from general fuel combustion, gas flaring, petroleum refining, vegetation burning and biomass burning, municipal waste burning, sawdust burning, industrial processes [18 - 24]. However, the state of information on the extent of total suspended particulates from crude oil spill is still not sufficient most especially in Nigeria. While studying fine particulate emission from Deep Water Horizon crude oil spill, previous authors [25] had reported that the emitted particulates were in multiple folds greater than the background concentration of the environment. By nature, particulates from crude oil spill will contain organic pollutants such as benzene, toluene etc. making them of greater human health concern. The properties of the crude oil, media over which spillage occurs and the prevailing climatic conditions of temperature and humidity at the time of spill can influence particulate emissions and their spread. Nigerian crudes are generally classified at light crude on the basis of their API gravities [26]. Light crude oils have many advantages, but they are also susceptible to emission of air contaminants including particulates during spill.

The frequency of crude oil spill in the Niger Delta region of Nigeria is high with the potential to affect public health. As earlier pointed out, studies on ambient particulates are many in Nigeria but information on the specific contributions of crude oil spill to their ambient concentrations as well as their toxicities is yet to be reported.

The present study is therefore centered on the measurement to total suspended particulate (TSP) concentrations from laboratory crude oil spill simulation experiments. The simulation experiments help to eliminate the interference of particulates from other sources in the measured data and hence make it possible to isolate crude oil spill as the sole contributor to the measured concentration of particulates. The toxicity potentials of the emitted particulates were also determined to establish the health risk implications.

\section{EXPERIMENTAL SETUP}

Prior to the measurement of TSP emitted during crude oil spill, the properties of the crude oil samples (relative density, API gravity and viscosity) and those of the spill media (soil porosity, bulk density, organic matter content, $\mathrm{pH}$ of water) were determined. The determination of relative density and API gravity was in accordance with these references [26, 27] while that of viscosity followed ISO 9001, ASTM D444 and ASTM D52515 standard methods using Cannon-Fenske reverse flow viscometer [28, 29]. Soil sampling and determination of its properties were in accordance with the methods used by [30 - 33]. The environmental chamber $(0.6 \mathrm{~m} \times 0.6 \mathrm{~m} \times 1 \mathrm{~m})$ used for the study was equipped with $1000 \mathrm{~W}, 0.25 \mathrm{Hp}$ and $1000 \mathrm{RPM}$ heating, cooling and fan respectively while Kestrel 4500 weather tracker was used for measurement of micro climatic conditions (temperature, humidity and wind speed) within the chamber. The chamber test conditions, crude oil, soil and water properties are as summarized in Table 1, Table 2 and Table 3. About $593 \mathrm{~mL}$ of three different crude oil samples of Nigerian origin were spilled in the test box under four variations of climatic conditions and the total suspended particulates (TSP) concentrations were measured with a Quick Take portable sampler. The sampler is a portable and battery operated equipment with flow rate of $30 \mathrm{~L} / \mathrm{min}$ and several options of run time mode ( $5 \mathrm{~min}, 10 \mathrm{~min}$ and $15 \mathrm{~min}$ ) for either intermittent sampling or continuous run sampling. Individual particles are counted by deployment of an inbuilt scattered laser light while the corresponding mass concentration is determined with a proprietary algorithm and displayed on the screen. 
Table 1. Simulated environmental chamber climatic conditions.

\begin{tabular}{|l|c|c|c|c|}
\hline & $* \mathrm{~T} 1$ & $* \mathrm{~T} 2$ & $* \mathrm{~T} 3$ & $* \mathrm{~T} 4$ \\
\hline Temperature $\left({ }^{\circ} \mathrm{C}\right)$ & 15 & 25 & 35 & 45 \\
\hline Relative Humidity (\%) & 80 & 71 & 68 & 49 \\
\hline
\end{tabular}

*T1-T4 (Test conditions)

Table 2. Soil and Water Properties.

\begin{tabular}{|l|c|c|c|}
\hline Soil properties & & Water properties & \\
\hline Bulk density & $1.25 \pm 0.02 \mathrm{~g} / \mathrm{cm}^{3}$ & $\mathrm{pH}$ of fresh water & 6.9 \\
\hline Porosity & $51.10 \pm 3.50 \%$ & $\mathrm{pH}$ of sea water & 7.8 \\
\hline Particle density & $2.68 \pm 0.10 \mathrm{~g} / \mathrm{cm}^{3}$ & - & - \\
\hline Organic matter content & $2.48 \pm 0.03 \%$ & - & - \\
\hline
\end{tabular}

Table 3. Properties of Crude Oil Samples.

\begin{tabular}{|c|c|c|c|c|}
\hline $\begin{array}{c}\text { Crude oil } \\
\text { samples }\end{array}$ & $\begin{array}{c}\text { Density }(\rho) \\
\mathrm{g} / \mathrm{mL}\end{array}$ & Specific gravity & Viscosity $(\mu) \mathrm{mm}^{2} / \mathrm{s}$ & API gravity \\
\hline A & $0.85 \pm 0.06$ & 0.83 & $7.17 \pm 1.12$ & 38.00 \\
\hline B & $0.87 \pm 0.04$ & 0.84 & $7.23 \pm 1.50$ & 34.00 \\
\hline C & $0.88 \pm 0.02$ & 0.86 & $7.41 \pm 1.21$ & 32.00 \\
\hline
\end{tabular}

Subsequently, the toxicity potential (TP) which is the ratio of measured ambient concentration (MTSP) of a pollutant to the statutory concentration limit (STSP) set for that pollutant in ambient was determined following methods earlier used by [5, 34, 35] as captured in Equation 1 . The statutory limits adopted include those set by Nigeria's Federal Ministry of Environment (FM), World Bank (WB) and the World Health Organization (WHO) as reported in [36-38].

$$
\mathrm{TP}=\frac{\mathrm{MTSP}}{\mathrm{STSP}}
$$

Prior to the deployment of equation 1, the measured 3-hour averaging period concentrations $\left(\mathrm{C}_{i}\right)$ were first extrapolated to 24 -hour averaging period concentration $\left(\mathrm{C}_{\mathrm{d}}\right)$ with an atmospheric stability formula proposed by [39] as show in equation 2 and equation 3, respectively:

$$
\begin{aligned}
& \mathrm{C}_{\mathrm{d}}=\mathrm{C}_{i} \times \mathrm{F} \\
& \mathrm{F}=\left(\frac{\mathrm{t}_{i}}{\mathrm{t}_{d}}\right)^{n}
\end{aligned}
$$

where $C_{d}$ is concentration at the desired averaging period $\left(t_{d}\right) ; C_{i}-$ measured concentration at the averaging period $\left(t_{i}\right) ; F$ - factor to convert from the averaging period $t_{i}$ to the averaging period $t_{d} ; n$ - the atmospheric stability dependent exponent and was assumed to be 0.28 .

\section{RESULTS AND DISCUSSION}

The 3-hour averaging period measured TSP concentrations and their corresponding 24-hour averaging period extrapolated concentrations at temperatures between $15^{\circ} \mathrm{C}$ and $35^{\circ} \mathrm{C}$ for spillage of the three crude oil samples over sea water (SW), fresh water (FW) and soil (S) are as summarized in Table 4, Table 5 and Table 6. The 3-hour averaging period measured concentrations of TSP emitted by sample A were between $334.37-1045.9 \mu \mathrm{gm}^{-3}$, $334.71-1046.25 \mu \mathrm{gm}^{-3}$ and $442.87-626.9 \mu \mathrm{gm}^{-3}$ for spill over sea water, fresh water and soil respectively while the corresponding 24 - hour averaging period extrapolated concentrations were $186.79-584.28 \mu \mathrm{gm}^{-3}, 186.98$ -

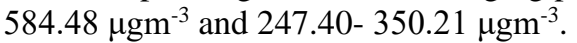

Table 4. Measured and extrapolated TSP concentrations from sample A $\left(\mu \mathrm{gm}^{-3}\right)$.

\begin{tabular}{|c|c|c|c|c|c|c|}
\hline $\begin{array}{c}\text { Climatic } \\
\text { Condition }\end{array}$ & $\begin{array}{c}* \text { Sea Water } \\
(\mathrm{SW})\end{array}$ & $\begin{array}{c}\text { Extrapolate } \\
\mathrm{d}(\mathrm{SW})\end{array}$ & $\begin{array}{c}* \text { Fresh } \\
\text { Water(FW) }\end{array}$ & $\begin{array}{c}\text { Extrapolated } \\
(\mathrm{FW})\end{array}$ & $*$ Soil $(\mathrm{S})$ & $\begin{array}{c}\text { Extrapolate } \\
\mathrm{d}(\mathrm{S})\end{array}$ \\
\hline $15^{\circ} \mathrm{C}, 80 \%$ & 334.37 & 186.79 & 334.71 & 186.98 & 452.17 & 252.60 \\
\hline
\end{tabular}




\begin{tabular}{|c|c|c|c|c|c|c|}
\hline $25^{\circ} \mathrm{C}, 71 \%$ & 445.97 & 249.14 & 446.32 & 249.33 & 442.87 & 247.40 \\
\hline $35^{\circ} \mathrm{C}, 68 \%$ & 406.23 & 226.94 & 406.58 & 227.13 & 626.9 & 350.21 \\
\hline $45^{\circ} \mathrm{C}, 49 \%$ & 1045.9 & 584.28 & 1046.25 & 584.48 & 533.3 & 297.92 \\
\hline
\end{tabular}

Table 5. Measured and extrapolated TSP concentrations from sample B $\left(\mu \mathrm{gm}^{-3}\right)$.

\begin{tabular}{|c|c|c|c|c|c|c|}
\hline $\begin{array}{c}\text { Climatic } \\
\text { Condition }\end{array}$ & $\begin{array}{c}* \text { Sea Water } \\
(\mathrm{SW})\end{array}$ & $\begin{array}{c}\text { Extrapolated } \\
(\mathrm{SW})\end{array}$ & $\begin{array}{c}\text { *Fresh } \\
\text { Water } \\
(\mathrm{FW})\end{array}$ & $\begin{array}{c}\text { Extrapolated } \\
(\mathrm{FW})\end{array}$ & *Soil (S) & $\begin{array}{c}\text { Extrapolated } \\
(\mathrm{S})\end{array}$ \\
\hline $15^{\circ} \mathrm{C}, 80 \%$ & 328.37 & 183.44 & 328.71 & 183.63 & 446.17 & 249.25 \\
\hline $25^{\circ} \mathrm{C}, 71 \%$ & 439.97 & 245.78 & 440.32 & 245.98 & 436.87 & 244.05 \\
\hline $35^{\circ} \mathrm{C}, 68 \%$ & 348.23 & 194.54 & 384.58 & 214.84 & 604.9 & 337.92 \\
\hline $45^{\circ} \mathrm{C}, 49 \%$ & 1023.9 & 571.99 & 1024.25 & 572.19 & 511.3 & 285.63 \\
\hline
\end{tabular}

Table 6. Measured and extrapolated TSP concentrations from sample $\mathrm{C}\left(\mu \mathrm{gm}^{-3}\right)$.

\begin{tabular}{|c|c|c|c|c|c|c|}
\hline $\begin{array}{c}\text { Climatic } \\
\text { Condition }\end{array}$ & $\begin{array}{c}* \text { Sea Water } \\
(\mathrm{SW})\end{array}$ & $\begin{array}{c}\text { Extrapolated } \\
(\mathrm{SW})\end{array}$ & $\begin{array}{c}* \text { Fresh } \\
\text { Water(FW) }\end{array}$ & $\begin{array}{c}\text { Extrapolated } \\
(\mathrm{FW})\end{array}$ & $*$ Soil $(\mathrm{S})$ & $\begin{array}{c}\text { Extrapolated } \\
(\mathrm{S})\end{array}$ \\
\hline $15^{\circ} \mathrm{C}, 80 \%$ & 328.37 & 183.44 & 328.71 & 183.63 & 446.17 & 249.25 \\
\hline $25^{\circ} \mathrm{C}, 71 \%$ & 439.97 & 245.78 & 440.32 & 245.98 & 436.87 & 244.05 \\
\hline $35^{\circ} \mathrm{C}, 68 \%$ & 348.23 & 194.54 & 384.58 & 214.84 & 604.9 & 337.92 \\
\hline $45^{\circ} \mathrm{C}, 49 \%$ & 1023.9 & 571.99 & 1024.25 & 572.19 & 511.3 & 285.63 \\
\hline
\end{tabular}

*Measured concentration

For sample B, the 3-hour averaging period measured concentrations of TSP emitted were between 328.37 -1023.90 $\mu \mathrm{gm}^{-3}, 328.71-1024.25 \mu \mathrm{gm}^{-3}$ and $446.17-604.90 \mu \mathrm{gm}^{-3}$ while the corresponding 24-hour averaging period extrapolated concentrations were $183.44-571.99 \mu \mathrm{gm}^{-3}, 183.63-572.19 \mu \mathrm{gm}^{-3}$ and $244.05-337.92 \mu \mathrm{gm}^{-3}$ for the same spill media and temperature range respectively. In the same vein, the 3-hour averaging period measured

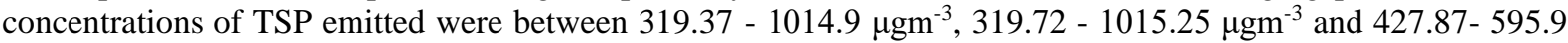

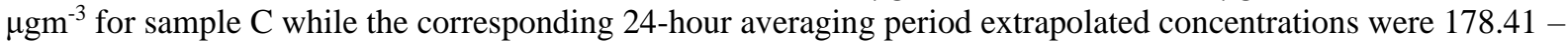
$566.96 \mu \mathrm{gm}^{-3}, 178.61-567.16 \mu \mathrm{gm}^{-3}$ and $332.89-280.60 \mu \mathrm{gm}^{-3}$ for the same spill media and range of temperature respectively.

Due to crude oil property factors (viscosity, API and specific gravity), the least and maximum emitted concentrations of TSP were obtained from sample A and sample $C$ respectively. This is expected since the viscosities of the samples were in the order $\mathrm{A}<\mathrm{B}<\mathrm{C}$. Generally, it was observed that increase in temperature from $15{ }^{\circ} \mathrm{C}$ to $45^{\circ} \mathrm{C}$ favoured the emission of particulates across all spill media for the three crude oil samples. This may also be associated with the reduction in viscosity as temperature rises. The maximum emitted TSP of $1,046.25 \mu \mathrm{gm}^{-3}$ was obtained from the spill of sample A over fresh water at $45^{\circ} \mathrm{C}$.

To put the results into proper perspective, the extrapolated concentrations were compared with the regulatory limit set for the pollutant in ambient air. The national standard set for TSP by Nigeria's Federal Ministry of Environment (FM) is $250 \mu \mathrm{gm}^{-3}$ [36]. For sample A, the extrapolated TSP concentrations breached the recommended limit for offshore (sea water and fresh water) spill at $45^{\circ} \mathrm{C}$ and onshore spill at $15^{\circ} \mathrm{C}, 35^{\circ} \mathrm{C}$ and $45^{\circ} \mathrm{C}$ as earlier presented in Table 3. In the case of sample B, the recommended limit was also exceeded for offshore spill at $45^{\circ} \mathrm{C}$ and onshore spill at $35^{\circ} \mathrm{C}$ and $45^{\circ} \mathrm{C}$ as presented in Table 4. Similar observations as experienced for sample B were observed for sample $\mathrm{C}$ (Table 6).

When the lower limit value of $150 \mu \mathrm{gm}^{-3}$ recommended by WHO (WHO $\mathrm{LL}_{\mathrm{L}}$ ) was used as the basis for comparison, the 24-hour extrapolated concentrations of TSP exceeded the limit at all temperatures and across all spill media, an indication that the ambient air might not be really safe especially for people having history of respiratory disease when oil spill occurs. The situation was a bit different when the WHO's upper limit (WHO $\mathrm{UL}_{\text {) }}$ of $230 \mu \mathrm{gm}^{-3}$ for TSP was applied. The number of exceedances was 11 times more than when Nigeria's national standard was applied.

The toxicity potentials of total suspended particulates emitted by crude oil samples A, B and C are summarized in Table 7, Table 8 and Table 9 respectively. When stringent regulations (WHO lower limit and World Bank limit) were applied, the toxicity potentials exceeded 1.0 at all temperatures and over all spill media. Previous authors [5, $34,35]$ had reported that toxicity potential value that is greater than or equal to 1.0 is an indication that dwellers 
around that airshed are exposed to serious health risks. Even with more relaxed statutory limits such as $230 \mu \mathrm{gm}^{-}$

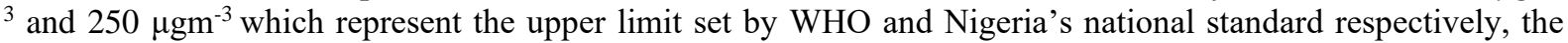
toxicity potentials still exceeded 1.0 in several instances and at $45^{\circ} \mathrm{C}$, the air condition with respect to suspended total particulates was highly toxic irrespective of the pollutant statutory limit used.

For samples A, B and C, the largest toxicity potential values of 7.3, 7.15 and 7.09 were obtained over fresh water at $45^{\circ} \mathrm{C}$ while the least values of $0.73,0.75$ and 0.71 were obtained over the sea water at $15^{\circ} \mathrm{C}$. Temperature and crude oil properties were observed to be the predominant factors influencing the emission rates and consequently the toxicity potentials of ambient suspended particulates.

Table 7. Toxicity potentials of total suspended particulate for spillage of sample A over different media.

\begin{tabular}{|l|c|c|c|c|c|c|c|c|c|c|c|c|}
\hline $\begin{array}{c}\text { Climatic } \\
\text { Condition }\end{array}$ & $\begin{array}{c}\mathrm{FM} \\
(\mathrm{SW})\end{array}$ & $\begin{array}{c}\mathrm{WHO}_{\mathrm{LL}} \\
(\mathrm{SW})\end{array}$ & $\begin{array}{c}\mathrm{WHO}_{\mathrm{UL}} \\
(\mathrm{SW})\end{array}$ & $\begin{array}{c}\mathrm{WB} \\
(\mathrm{SW})\end{array}$ & $\begin{array}{c}\mathrm{FM} \\
(\mathrm{FW})\end{array}$ & $\begin{array}{c}\mathrm{WHO}_{\mathrm{LL}} \\
(\mathrm{FW})\end{array}$ & $\begin{array}{c}\mathrm{WHO}_{\mathrm{UL}} \\
(\mathrm{FW})\end{array}$ & $\begin{array}{c}\mathrm{WB} \\
(\mathrm{FW})\end{array}$ & $\begin{array}{c}\mathrm{FM} \\
(\mathrm{S})\end{array}$ & $\begin{array}{c}\mathrm{WHO}_{\mathrm{LL}} \\
(\mathrm{S})\end{array}$ & $\begin{array}{c}\mathrm{WHO}_{\mathrm{UL}} \\
(\mathrm{S})\end{array}$ & $\begin{array}{c}\mathrm{WB}^{\circ} \\
(\mathrm{S})\end{array}$ \\
\hline $\begin{array}{l}\mathrm{T}=15^{\circ} \mathrm{C} \\
\mathrm{RH}=80 \%\end{array}$ & 0.75 & 1.25 & 0.81 & 2.33 & 0.75 & 1.25 & 0.81 & 2.34 & 1.01 & 1.68 & 1.10 & 3.16 \\
\hline $\begin{array}{l}\mathrm{T}=25^{\circ} \mathrm{C} \\
\mathrm{RH}=71 \%\end{array}$ & 1.00 & 1.66 & 1.08 & 3.11 & 1.00 & 1.66 & 1.08 & 3.12 & 0.99 & 1.65 & 1.08 & 3.09 \\
\hline $\begin{array}{l}\mathrm{T}=35^{\circ} \mathrm{C} \\
\mathrm{RH}=68 \%\end{array}$ & 0.91 & 1.51 & 0.99 & 2.84 & 0.91 & 1.51 & 0.99 & 2.84 & 1.40 & 2.33 & 1.52 & 4.38 \\
\hline $\begin{array}{l}\mathrm{T}=45^{\circ} \mathrm{C} \\
\mathrm{RH}=49 \%\end{array}$ & 2.34 & 3.9 & 2.54 & 7.3 & 2.34 & 3.90 & 2.54 & 7.31 & 1.19 & 1.99 & 1.30 & 3.72 \\
\hline
\end{tabular}

Table 8. Toxicity potentials of total suspended particulate for spillage of sample B over different media.

\begin{tabular}{|c|c|c|c|c|c|c|c|c|c|c|c|c|}
\hline $\begin{array}{l}\text { Climatic } \\
\text { Condition }\end{array}$ & $\begin{array}{c}\text { FM } \\
(\mathrm{SW})\end{array}$ & $\begin{array}{c}\mathrm{WHO}_{\mathrm{LL}} \\
(\mathrm{SW})\end{array}$ & $\begin{array}{l}\mathrm{WHO}_{\mathrm{UL}} \\
\text { (SW) }\end{array}$ & $\begin{array}{l}\text { WB } \\
(\mathrm{SW})\end{array}$ & $\begin{array}{l}\text { FM } \\
(\mathrm{FW})\end{array}$ & $\begin{array}{c}\mathrm{WHO}_{\mathrm{LL}} \\
(\mathrm{FW})\end{array}$ & $\begin{array}{c}\mathrm{WHO}_{\mathrm{UL}} \\
(\mathrm{FW})\end{array}$ & $\begin{array}{l}\text { WB } \\
(\mathrm{FW})\end{array}$ & $\begin{array}{l}\text { FM } \\
(\mathrm{S})\end{array}$ & $\begin{array}{l}\mathrm{WHO}_{\mathrm{LL}} \\
(\mathrm{S})\end{array}$ & $\begin{array}{l}\mathrm{WHO}_{\mathrm{UL}} \\
(\mathrm{S})\end{array}$ & $\begin{array}{l}\text { WB } \\
(\mathrm{S})\end{array}$ \\
\hline $\begin{array}{l}\mathrm{T}=15^{\circ} \mathrm{C}, \\
\mathrm{RH}=80 \%\end{array}$ & 0.73 & 1.22 & 0.80 & 2.29 & 0.73 & 1.22 & 0.80 & 2.30 & 1.00 & 1.66 & 1.08 & 3.12 \\
\hline $\begin{array}{l}\mathrm{T}=25^{\circ} \mathrm{C}, \\
\mathrm{RH}=71 \%\end{array}$ & 0.98 & 1.64 & 1.07 & 3.07 & 0.98 & 1.64 & 1.07 & 3.07 & 0.98 & 1.63 & 1.06 & 3.05 \\
\hline $\begin{array}{l}\mathrm{T}=35^{\circ} \mathrm{C}, \\
\mathrm{RH}=68 \%\end{array}$ & 0.78 & 1.30 & 0.85 & 2.43 & 0.86 & 1.43 & 0.93 & 2.69 & 1.35 & 2.25 & 1.47 & 4.22 \\
\hline $\begin{array}{l}\mathrm{T}=45^{\circ} \mathrm{C}, \\
\mathrm{RH}=49 \%\end{array}$ & 2.29 & 3.81 & 2.49 & 7.15 & 2.29 & 3.81 & 2.49 & 7.15 & 1.14 & 1.90 & 1.24 & 3.57 \\
\hline
\end{tabular}

Table 9. Toxicity potentials of total suspended particulate for spillage of sample C over different media.

\begin{tabular}{|c|c|c|c|c|c|c|c|c|c|c|c|c|}
\hline $\begin{array}{c}\text { Climatic } \\
\text { Condition }\end{array}$ & $\begin{array}{c}\text { FM } \\
(\mathrm{SW})\end{array}$ & $\begin{array}{c}\mathrm{WHO}_{\mathrm{LL}} \\
(\mathrm{SW})\end{array}$ & $\begin{array}{c}\mathrm{WHO}_{\mathrm{UL}} \\
(\mathrm{SW})\end{array}$ & $\begin{array}{l}\text { WB } \\
(\mathrm{SW})\end{array}$ & $\begin{array}{c}\text { FM } \\
(\mathrm{FW})\end{array}$ & $\begin{array}{c}\mathrm{WHO}_{\mathrm{LL}} \\
(\mathrm{FW})\end{array}$ & $\begin{array}{c}\mathrm{WHO}_{\mathrm{UP}} \\
(\mathrm{FW})\end{array}$ & $\begin{array}{l}\text { WB } \\
(\mathrm{FW})\end{array}$ & $\begin{array}{l}\text { FM } \\
(\mathrm{S}) \\
\end{array}$ & $\begin{array}{c}\mathrm{WHO}_{\mathrm{LL}} \\
(\mathrm{S})\end{array}$ & $\begin{array}{c}\mathrm{WHO}_{\mathrm{UP}} \\
(\mathrm{S})\end{array}$ & $\begin{array}{l}\text { WB } \\
(\mathrm{S})\end{array}$ \\
\hline $\begin{array}{l}\mathrm{T}=15^{\circ} \mathrm{C}, \\
\mathrm{RH}=80 \%\end{array}$ & 0.71 & 1.19 & 0.78 & 2.23 & 0.71 & 1.19 & 0.78 & 2.23 & 0.98 & 1.63 & 1.06 & 3.05 \\
\hline $\begin{array}{l}\mathrm{T}=25^{\circ} \mathrm{C}, \\
\mathrm{RH}=71 \%\end{array}$ & 0.96 & 1.61 & 1.05 & 3.01 & 0.96 & 1.61 & 1.05 & 3.01 & 0.96 & 1.59 & 1.04 & 2.99 \\
\hline $\begin{array}{l}\mathrm{T}=35^{\circ} \mathrm{C}, \\
\mathrm{RH}=68 \%\end{array}$ & 0.84 & 1.40 & 0.91 & 2.62 & 0.84 & 1.40 & 0.91 & 2.62 & 1.33 & 2.22 & 1.45 & 4.16 \\
\hline $\begin{array}{l}\mathrm{T}=45^{\circ} \mathrm{C}, \\
\mathrm{RH}=49 \%\end{array}$ & 2.27 & 3.78 & 2.47 & 7.09 & 2.27 & 3.78 & 2.47 & 7.09 & 1.12 & 1.87 & 1.22 & 3.51 \\
\hline
\end{tabular}

\section{CONCLUSIONS}

Nigerian being a major oil and gas nation frequently experiences crude oil spill along its production corridors with potentials to emit particulates. Emissions of particulates under different climatic conditions and over three spill media have been investigated using three separate samples of Nigerian crude oil.

Results showed that considerable amount of particulates were emitted during spill over fresh water, sea water and soil. The WHO (lower limit) and World Bank statutory limits set for TSP were exceeded in all cases. The 250

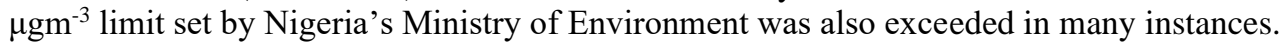

The toxicity potential of particulates associated with crude oil spill in Nigeria is thus considered to be a major air quality hazard. Adequate protection of cleaning up workers and sensitization of the public are considered top priorities and are therefore recommended in event of crude oil spill. 


\section{REFERENCES}

[1] Wyzga, R.E., Rohr A.C., Long-term particulate matter exposure: attributing health effects to individual PM components, Journal of the Air Waste and Management Association, vol. 65, no. 5, 2005, p. 523-543.

[2] Thompson, J.E., Airborne particulate matter human exposure and health effects, Journal of Occupational Environmental Medicine, vol. 60, no. 5, 2018, p. 392-423.

[3] Okedere, O.B., Fakinle, B.S., Ajala O.E., Particulates and carbon monoxide pollution on production floor of steel recycling plant, Environmental Quality Management, vol. 28, no. 4, 201, p. 1-4.

[4] Kumar, P., Kalaiarasan, G., Porter, A.E., Pinna, A., Klosowski, M.M., Demokritou, P., Chung, K.F., Pain, C., Arvind, D.K., Arcucci, R., Adcock, I.M., Dilliway, C., An overview of fine and ultrafine particle collection for physicochemical characterization and toxicity assessments, Science of the Total Environment, vol. 756, 143553, 2021.

[5] Fakinle, B.S., Sonibare, J.A., Akeredolu, F.A., Okedere, O.B. and Jimoda, L.A., Toxicity potential of particulates in the airshed of haulage vehicle park, GNEST vol. 15, no. 4, 2013, p. 466-473.

[6] Comunian, S., Dongo, D., Milani, C., Palestini, P., Air pollution and COVID-19: the role of particulate matter in the spread and increase of COVID-19's morbidity and mortality, International Journal of Environmental Research and Public Health, vol. 17, no. 12, 2020, p. 4487.

[7] Okedere, O.B., Elehinafe, F.B., Oyelami, S. Ayeni, A.O., Drivers of anthropogenic air emissions in Nigeria A review, Heliyon, vol. 7, no. 3, 2021, p. e06398.

[8] Xing, Y.F., Xu, Y.H., Shi, M.H., Lian, Y.X., The impact of PM2.5 on the human respiratory system, Journal Thoracic Disease, vol. 8, no.1, 2016, p. E69-E74.

[9] Schraufnagel, D.E., The health effects of ultrafine particles, Experimental and Molecular Medicine, vol. 52, 2020, p. 311-317.

[10] Terzano, C., Di Stefano, F., Conti, V., Graziani, E., Petroianni, A., Air pollution ultrafine particles: toxicity beyond the lung, European Review for Medical and Pharmacological Sciences, vol. 14, no. 10, 2010, p. 809-821. [11] Schraufnagel, D.E., Balmes, J.R., Cowl, C.T., Matteis, S.D., Jung, S., Mortimer, K., Perez-Padilla, R., Rice, M.B., Riojas-Rodriguez, H., Sood, A., Thurston, G.D., To, T., Vanker, A., Wuebbles, D.J., Air pollution and noncommunicable diseases: A review by the Forum of International Respiratory Societies' Environmental Committee, Part 1: the damaging effects of air pollution, Chest, vol. 155, 2019, p. 409-416.

[12] De Hartog, J.J., Hoek, G., Peters, A., Timonen, K.L., Ibald-Mulli, A., Brunekreef, B., Heinrich, J., Tiittanen, P., Wijnen, J.H., Kreyling, W. Kulmala, M., Effects of fine and ultrafine particles on cardiorespiratory symptoms in elderly subjects with coronary heart disease: the ULTRA study, American Journal of Epidemiology, vol. 157, no. 7, 2003, p. 613-623.

[13] Mazzoli-Rocha, F., Fernandes, S., Einicker-Lamas, M., Zin, W.A., Roles of oxidative stress in signaling and inflammation induced by particulate matter, Cell Biology and Toxicology, vol. 26, no. 5, 2010, p. 481-498.

[14] Genc, S., Zadeoglulari, Z., Fuss, S.H. Genc, K., The adverse effects of air pollution on the nervous system, Journal of Toxicology, vol. 2012, no. 4, 2012, p. 782462.

[15] Oberdorster, G., Elder, A., Rinderknecht, A., Nanoparticles and the brain: Cause for concern?, Journal of Nanoscience and Nanotechnology, vol. 9, no. 8, 2009, p. 4996-5007.

[16] Peters, A., Veronesi, B., Calderon-Garciduenas, L., Gehr, P., Chen, L.C., Geiser, M., Reed, W., Rutishauser, B.R., Schurch, S., Schulz, H., Translocation and potential neurological effects of fine and ultrafine particles a critical update, Particle and Fibre Toxicology, vol. 3, no. 13, 2006, p. 1-13.

[17] Sonibare, J.A., Air pollution implications of Nigeria's present strategy on improved electricity generation, Energy Policy, vol. 38, no. 10,2010, p. 5783-5789.

[18] Oladimeji, T., E Sonibare, J.A., Odunfa, K.M., Ayeni, A., Modeling of criteria air pollutant emissions from selected Nigeria petroleum refineries, Journal of Power and Energy Engineering, vol. 3, no. 6: 2015, p. 31-45. [19] Asubiojo, O.I., Pollution sources in the Nigerian environment and their health implications, IFE Journal of Science, vol. 18, no. 4, 2016, p. 973-980.

[20] Okedere, O.B., Olalekan, A.P., Fakinle, B.S., Elehinafe, F.B., Odunlami, O.A., Sonibare J. A., Urban air pollution from the open burning of municipal solid waste. Environmental Quality Management, vol. 28, 2019 , p. 67-74.

[21] Oki, A.A., Fakinle, B.S., Sonibare, J.A., Criteria air pollutants from cement production in Nigeria, Environmental Quality Management, vol. 28, no. 1, 2019, p. 107-113.

[22] Giwa, S.O., Nwaokocha, C.N., Kuye, S.I., Adama, K.O., Gas flaring attendant impacts of criteria and particulate pollutants: A case of Niger Delta region of Nigeria, Journal of King Saud University - Engineering Sciences, vol. 39, no. 3, 2019, p. 209-217. 
[23] Giwa, S.O., Nwaokocha, C.N., Layeni A.T., Inventory of kiln stacks emissions and health risk assessment: Case of a cement industry in Southwest Nigeria, African Journal of Science, Technology, Innovation and Development, vol. 11, no. 3, 2019, p. 299-312.

[24] Elehinafe, F.B., Mamudu, A.O., Okedere, O.B., Ibitioye A., Risk assessment of chromium and cadmium emissions from the consumption of premium motor spirit (PMS) and automotive gas oil (AGO) in Nigeria, Heliyon, vol. 6, 2020, e05301, p. 1-7.

[25] Nance, E., King, D., Wright, B., Bullard, R.D., Ambient air concentrations exceeded health-based standards for fine particulate matter and benzene during the Deepwater Horizon oil spill, Journal of the Air and Waste Management Association, vol. 66, no. 2, 2016, p. 224-236.

[26] Al-Dahhan, W.H., Mahmood S. M.A., Classification of crude oils and its fractions on the basis of paraffinic naphthenic and aromatics, Al-Naharain Journal of Science, vol. 22, no. 3, 2019, p. 35-42.

[27] Daubert, T.E., American Petroleum Institute Technical Data Book, $6^{\text {th }}$ ed. Washington, DC, vol. 21, no. 3, 1997, p. 25-33.

[28] Fan, T., Viscosity measurement using Cannon- Fenske viscometers, 2021, http://www.prrc.nmt.edu/groups/petrophysics/media/pdf/viscometer (8.08.2021).

[29] Fitch, B. Viscometers: a practical guide, machine lubrication, Nora Corporation, 2013, https://www.machinerylubrication.com/Read/29451/anatomy-of-viscometer (9.08.2021).

[30] Song, H.T., Oghenejoboh K.M., Puyate Y.T., Abowel M.F.N., Concentration distribution of spilled petroleum in different soil, effects of volume of oil on spatial spread, Pollution research, vol. 27, no. 4, 1990, p. 605-610.

[31] Black, C.A., Evans, D.D., Ensminger, L.E., Whils, J.L., Clerk, F.E., Dinauer, R.C., Methods of soil analysis, Part 2. Chemical and Microbio-logical properties, American Society of Agronomy, Inc. Madison, Wisconsin, 1979, p. 1142-1753.

[32] Juo, A.S.R., Selected methods for soil and plant analysis, International Institute of Tropical Agriculture (I.I.T.A) manual series no. 1, Ibadan, Nigeria, 1978.

[33] Ayotamuno, J. M., Kogbara R. B., Determining the tolerance level of Zea mays (maize) to a crude oil polluted agricultural soil, African Journal of Biotechnology, vol. 6, no. 11, 2007, p. 1332-1337.

[34] Sonibare, J.A., Akeredolu, F.A., Osibanjo, O., Latinwo, I., ED-XRF analysis of total suspended particulates from enamelware manufacturing industry, American Journal of Applied Science, vol. 2, no. 2, 2005, p. 573-578.

[35] Owoade, O.K., Olise, F.S., Obioh, I.B., Olaniyi, H.B., Ferrero, L., Bolzacchini, E., EDXRF elemental assay of airborne particulates: A case study of an iron and steel smelting industry, Lagos, Nigeria, Scientific Research and Essay, vol. 4, no. 11, 2009, p. 1342-1347.

[36] Federal Environmental Protection Agency (FEPA), Guidelines to standards for environmental pollution control in Nigeria, 1991, https://lawsofnigeria.placng.org/laws/F10.pdf. (12.08.2021).

[37] World Bank, Pollution prevention and abatement handbook, World Bank Group, Washington DC, 1998, https://documents1.worldbank.org/curated/en/758631468314701365/pdf/multiOpage.pdf. (12.08.2021).

[38] World Health Organization (WHO), Sulfur oxides and suspended particulate matter, Environmental Health Criteria 8, Geneva, 1979, https://apps.who.int/iris/bitstream/handle/10665/39560/9241540680-eng.pdf (12.08.2021).

[39] Bashar, M.A., Kamel, K.A., Khaldoun, M.S., Assessment of air pollutants emissions from a cement plant: A case study in Jordan, Jordan Journal of Civil Engineering, vol. 3, no. 3, 2009, p. 265-282. 